\title{
Article \\ Small WORLD: Ancient Egyptian Architectural Replicas from the Tomb of Meketre
}

\author{
Arlette David (D)
}

check for

updates

Citation: David, A. Small WORLD: Ancient Egyptian Architectural Replicas from the Tomb of Meketre. Humans 2021, 1, 18-28. https:// doi.org/10.3390/humans1010004

Academic Editor: Kevin M. Kelly

Received: 16 July 2021

Accepted: 8 September 2021

Published: 15 September 2021

Publisher's Note: MDPI stays neutral with regard to jurisdictional claims in published maps and institutional affiliations.

Copyright: (C) 2021 by the author. Licensee MDPI, Basel, Switzerland. This article is an open access article distributed under the terms and conditions of the Creative Commons Attribution (CC BY) license (https:/ / creativecommons.org/licenses/by/ $4.0 /)$.
Mount Scopus, Institute of Archaeology, The Hebrew University of Jerusalem, Jerusalem 91905, Israel; arlette.david@mail.huji.ac.il

\begin{abstract}
The paper presents a study of the context, functions, and rationale behind architectural replicas sealed off in ancient Egyptian tombs, the finest exemplars of which having been excavated in the Theban tomb of Meketre (ca. 2000 B.C.). The analysis is preceded by clarifications regarding the terminology used, the point of view from which they have to be considered, and the developments that led to their presence in the funerary assemblage. It is suggested that in the sealed 'replicas chamber' or burial chamber in which they were deposited, it was mainly the winged $b a$, a connective agent between the worlds of life, death, and eternity, that was meant to enter the imaginary realm of the replicas and feed the deceased in order to revivify him.
\end{abstract}

Keywords: ancient Egypt; Middle Kingdom; funerary assemblage; architectural replicas; miniatures

\section{Introduction}

The appeal of ancient Egyptian architectural replicas exhibited in museums is endlessly evinced by the number of visitors, children and adults, pressed around houses, granaries, and workshops, amazed by the level of intricacy in which human activities are portrayed inside the miniatures' walls. Produced from the Predynastic Period (as early as Naqada III, ca. 3200 B.C., see replica BM EA 35505 from el-Amra) [1] to the Graeco-Roman Period [2] (p. 1067) and mostly deposited in tombs, they are mainly attested from the late Old Kingdom to the early Middle Kingdom, the most impressive examples assembled during late Dynasty 11 [3] (p. 23) to early Dynasty 12 [4] (p. 21), [5] (ca. 2000 B.C., see [6] (pp. 407-413) for respective arguments) in the tomb of the king's chief steward and chancellor Meketre, located in the Theban necropolis of Assasif (TT 280). A chamber dug in the floor of the entrance corridor leading to the chapel, untouched since its sealing four thousand years ago, was found in 1920 by Herbert Winlock, revealing a deposit of diminutive (but not tiny) architectural and boat replicas, together with figures of offering bearers [7] (pp. 13-14).

Meketre's architectural replicas depict granaries, workshops, domestic gardens, and the livestock count in front of the owner's pavilion, similar to scenes depicted on the walls of many tomb chapels. One can compare, e.g., Meketre's cattle count replica Cairo JE 46724 [7] (pls. 13-14) with a parietal scene in Khafreankh's Giza tomb 7948 (Dynasty 5) [8] (pl. 9); Meketre's weaving workshop replica Cairo JE 46723 [7] (pls. 25-27) with the painted scene of Khnumhotep II at Beni Hasan (Dynasty 12) [9] (pl. 29), [10] (pl. 28); Meketre's carpentry replica Cairo JE 46722 [7] (pls. 28-29) with a scene in Khunes' Zawyet Sultan tomb (Dynasty 6) [8] (pl. 108); Meketre's butcher shop replica MMA 20.3.10 (Figure 1a) [7] (pls. 18-19) with a relief in Nesemnehu's Giza tomb (Dynasty 5-6) [8] (pl. 92). The parietal décor of Meketre's tomb had unfortunately been smashed to pieces, but the fragment of a fine-painted relief of a bull with a rug on its back (MMA 20.3.162) [4] (p. 21, Figure 25), [11] recalls the cattle count replica mentioned above (although the cattle are not saddled in the miniature). The quality of the painted relief and of the wooden replicas in the tomb is equally high (see, for instance, the skilled craftsmanship of the enclosed garden pair MMA 20.3.13 in Figure 1b and Cairo JE 46721) [7] (pls. 9-12), and the tomb surely must have been 
one of the finest of the Theban area [4] (pp. 22-23). Although, as it is often contended, crude replicas were substitutes for costly carved or painted wall décors in tombs of low-rank officials [2] (p. 1068), some members of the elite could obviously afford both (see, e.g., tomb of Niankhpepykem at Meir, Dynasty 6 [12] (pp. 66-69), [10]; Naga ed-Deir tombs [13] (pp. 78, 88)).

This paper aims to reevaluate the paradigm to which ancient Egyptian architectural replicas have been assigned, through a careful art historical analysis of their evolution leading to Meketre's sophisticated collection, their significance in the funerary assemblage, and their precise context inside the tomb. Far from being items of minor import, their relevance as part of an ensemble devoted to post-mortem revival was crucial for the contemporaneous elite funerary culture. With the help of the Coffin Texts, the corpus of funerary spells in use at the peak of production of architectural replicas, common assumptions about their presence and rationale in the burial assemblage will be examined and keys for their interpretation provided.

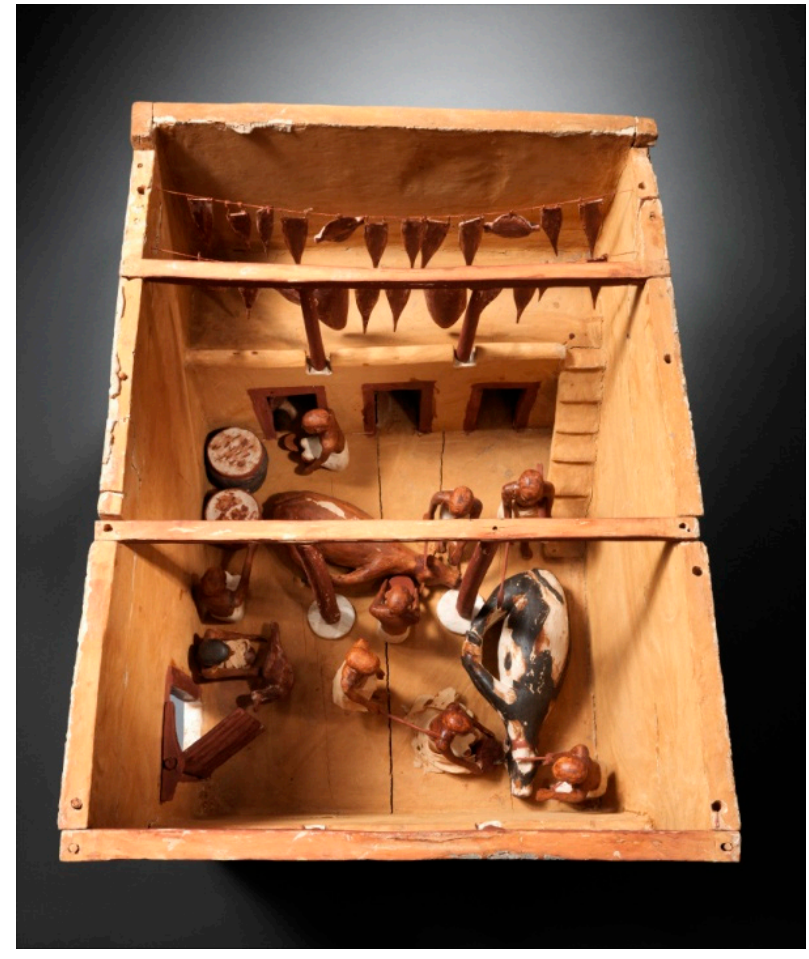

(a)

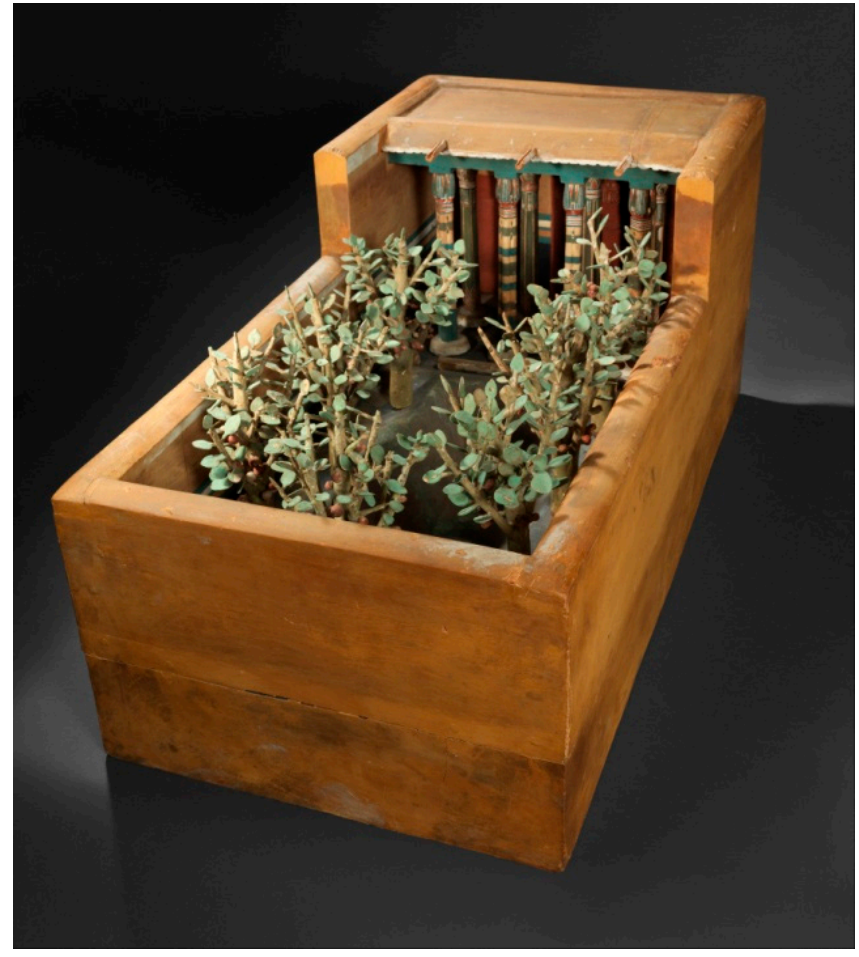

(b)

Figure 1. (a) Butcher shop MMA 20.3.10; (b) enclosed garden MMA 20.3.13.

\section{Materials and Methods}

This paper considers Meketre's collection of intact architectural replicas found in a secure context to examine their functions and rationale. The art historical analysis (description, relation with material and textual culture, interpretation, with a special focus on context) is preceded by clarifications regarding the terminology used, the point of view from which they have to be considered, and the development that led to their presence in the funerary assemblage. First Intermediate Period-Middle Kingdom funerary texts are used to assess the material.

Although recent scholarship deals with various aspects of miniatures, some of which is referred to in these pages, this paper is exclusively concerned with replicas found in ancient Egyptian burial context and with their main addressee. Petrie's 'soul houses', or rather clay offering trays that were laid above modest funerary pits, are not taken into consideration here [14] (pp. 14-20), [15] (p. 253), [16-19]. 


\section{Clarifications}

\subsection{Models or Replicas?}

I use the term replica (i.e., imitation) to designate the architectural miniatures to avoid the connotations of model (i.e., prototype) used by architects to visualize planned constructions. Ancient Egyptian architectural replicas represent granaries, workshops, and domestic spaces functioning as autonomous microcosms. The preference for replica is not motivated by the lack of formal 'realism' usually attached to models (see, e.g., the discussion of model vs. miniature in terms of realism in [18] (p. 121), [20] (pp. 28-32), [21] (p. 72), [22] (pp. 11-14), even though their scale and function imply per se a distorted reality [23] (pp. 99-100). Realism is not so much the concern of ancient Egyptian craftsmen and artists as are the significance and adequation that guaranty the potency of their creations [24] (pp. 83-86). Architectural replicas are part of a funerary décor and assemblage that constitutes a careful selection of items, texts, and 2D and 3D images devoted to the rebirth of the deceased. Such selection does not cover the reality of this world, but creates an environment on the verge of two planes of existence, pre and post-mortem, in which a limited array of needs is chosen to be met with the most adequate of means. Although mimesis and scaling are at the core of replicas, simplification remains a major constraint [22] (pp. 5-11), the same essentialism that pervades the Egyptian (icono)graphic system [24] (pp. 83-84). To ancient Egyptian eyes, unrealistic architectural replicas were certainly not 'dysfunctional', since their modus operandi was performative [25], [26] (pp. 21-24), [27] (pp. 411-413), [24] $(8,83,155,214-215,427)$, allowing things to be done with images as that may be done with words: a piece of bread, adequately depicted on the tomb wall and probably 'activated' during the funerary ritual, would function as well as the offering of a fresh loaf, a piece of clay in its shape inside a bakery replica, the word 'bread' in the offering formula written on the wall and/or pronounced in the liturgy.

\subsection{The Internal Point of View}

The art and power of the replicas do not reside in the eyes and hands of an external beholder. Often quoted, Levi-Strauss notes that 'all miniatures seem to have intrinsic aesthetic quality - and from what should they draw this constant virtue if not from the dimensions themselves?' He adds that they create the illusion that one can grasp the meaning of the whole object before the detail of its parts, comprehend the way it was manufactured, thus offering the viewer pleasant gratification [28] (pp. 23-24). In his work on miniatures, Mack remarks that reducing scale implies 'a corresponding exaggeration of content' [21] (p. 1). Furthermore, like the tombs' murals, replicas are often interpreted as status and identity indexes of the tomb owner in a stratified society [29] (pp. 371, 378), [30] (p. 162). Levi-Strauss and Mack's observations were not specifically related to ancient Egyptian architectural replicas and are pertinent only from the point of view of an external observer looking at a miniature (this is also the point of view adopted by Bailey for prehistoric figurines) [20] (pp. 26-44). On the contrary, ancient Egyptian architectural replicas were not primarily addressed to such a viewer; they were not meant to be contemplated by the visitors but rather to act from within. Like any image painted or carved in the tomb, replicas provided, by the perpetuation of mundane activities for the tomb owner's profit, the sustenance and framework necessary for his rebirth and eternal life. Moreover, Meketre's delicate replicas were purposefully hidden from the visitors' eyes, exclusively addressed and accessible to a deceased Meketre.

Thirty years ago, Roland Tefnin demonstrated how ancient Egyptian funerary imagery opposed the main Subject in the tomb-its deceased owner-to the Object, the activities performed for his benefit and subject to his monitoring [31]. The intended primary viewer of tomb murals was thus conceived as internal to the depiction, combining the roles of main protagonist and beneficiary. As such, the deceased owner is, in narratological terms, the focalizer of the depicted narrative, the eyes and unique point of view through which funerary scenes should be apprehended and understood before late Dynasty 18 [24] (p. 160). External viewers, such as the murals' artists, ritualists, and visitors, are only secondary 
focalizers whose perception is not the central issue in this context, even though they have their own role to play in the funerary environment. Considerations of social standing, decorum, ritual potency, and esthetic validation were important in relation to the burial of a (wo)man of high status, primarily so that it would perpetuate in the Afterlife the deceased owner's access to essential staples, relevant liturgy, and the social markers that had defined her/him in life.

For the deceased, the replicas were not downscaled ersatz, works of art, or accountant's tokens of ownership of the depicted assets. Replicas, like their mural counterparts, did not substitute for specific domains and workshops in his possession; they were meant to function on their own, independent plane, as generic icons for the depicted activities and contexts, and with all the necessary implements to do so. The deceased would not identify with the fascinated observer of exceptionally well-manufactured dollhouses, and architectural replicas were not just eternal signs of his identity and status, but symbolic [32] (p. 136) stages built for an afterlife performance. Replicas did not need the extreme delicacy and level of details of Meketre's gardens, workshops, and granaries to function properly; the care with which they were constructed fitted his standing in life and the Theban artistic blossoming of the time. The circumstances in which these architectural replicas developed are important for their comprehension and will be dealt with in what follows.

\section{From Isolated Active Figurines to Architectural Ensembles}

As mentioned earlier, architectural replicas are encountered since the predynastic period in funerary contexts (for a Dynasty 19 stone replica of a temple gateway, a votive gift to the temple of Heliopolis, see Brooklyn 49.183 [33]); such early (and rare) attempts at dispatching a miniature building with the dead foreshadow much later practices [34] (p. 36). Nevertheless, descriptions of the process that led to the development of full-fledged architectural replicas usually eschew this early stage in favor of Old Kingdom tombs of officials. These burials often include a superstructure (chapel, related rooms, passages) open to visitors and ritual officiants, its walls bearing a carved/painted décor, and a connected underground burial chamber (with related rooms) sealed off after burial, usually devoid of any parietal décor (Figure 2). Other configurations exist, for instance, without any superstructure or décor in the chapel. In any case, the vast majority of architectural replicas are deposited in the undecorated burial chamber, close to the coffin [29] (p. 76).

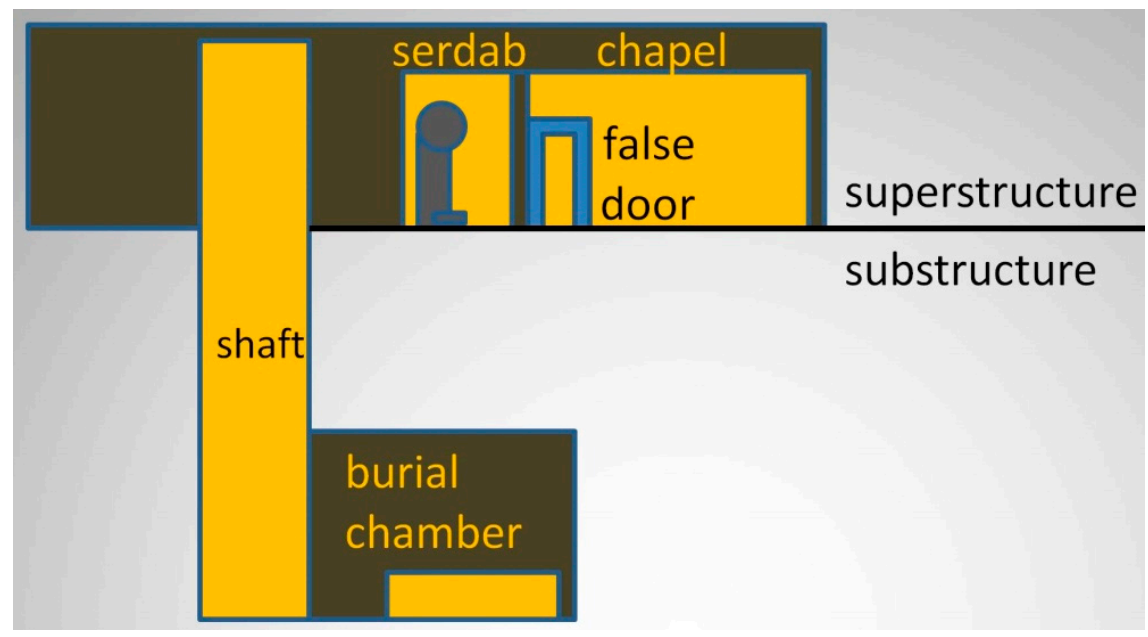

Figure 2. Schematic Old Kingdom tomb.

By late Dynasty 4-early Dynasty 5 (ca. 2450 B.C.), in the tombs' superstructure, the usually undecorated serdab (a closed cell equipped with statues of the tomb owner, sometimes also of close family members) [35] associated with the chapel's false door (for the deceased's access to the offerings deposited in the chapel), became the receptacle of limestone statuettes performing a menial activity. These figurines, invisible to visitors to the 
chapel [36] (p. 137) (except at Assiut [36] (p. 178)), provide for the needs of the deceased. Dubbed 'servant' or 'serving statues' in Egyptology [37-39], they are mainly involved in food production and rarely inscribed with the name of a family member. Rituals are performed in front of the sealed serdab [40] (p. 109), probably related to the statues and statuettes enclosed in it.

Although most burial chambers have no parietal décor, from late Dynasty $5 /$ early Dynasty 6 to the Middle Kingdom (ca. 2300-2000 B.C.), some depict offering lists and objects on their walls; few murals represent people involved in food production [40] (pp. 113-120), [41-43], [36] (p. 176). In rare cases, animated production scenes are displayed in both the chapel and burial chamber [42] (p. 58), [41] (p. 112). Moreover, with Dynasty 6 and the decline of the superstructure's serdab, statues of the deceased, his family, and wooden servant statuettes, sometimes associated in groups around similar activities and pinned on a board, are deposited in the vicinity of or inside the burial chamber (a statue of the deceased was also set up in the chapel for the mortuary cult). These trends attest to an evolution of the tomb's substructure concept: images of the deceased, offerings, and sustenance providers could be supplied around coffins and funerary assemblages, in a context deprived of ritual activity after inhumation.

From the First Intermediate Period to mid-Dynasty 12 (ca. 2200-1850 B.C.), replicas are closely associated with statues of the deceased and his coffin in the burial chamber [36] (p. 172). Gradually, the groups of anonymous figurines on their board become more intricate and surrounded by a low wall or enclosed in a structure with high walls, doors, partial roof, etc. The most sophisticated examples of architectural replicas are found in a 'replicas chamber' dug under the floor of the superstructure, as it is the case in Meketre's tomb [29] (p. 77). Eventually, during the reign of Senusret III (ca. 1850 B.C.), wooden replicas became rare [29] (pp. 384-385), [32] (220), [36] (p. 168-171, 180-181) due to the adoption of a different model of funerary material culture (a concept used by Willems [32] (p. 174)). This reign is marked by far-reaching political and social changes, some of these reflected in burial customs [44] (pp. 10-16), [45] (p. 6).

In sum, the superstructure was accessible to visitors, while most replicas were not: they were generally found close to the coffin in the crypt whose walls were rarely ornamented, or in a separate, undecorated sealed chamber beneath the superstructure (clay 'soul houses' are, of course, another matter since they were deposited as offering tables above modest pit-burials, see supra). They were not intended to be manipulated in the mortuary ritual. Was it a measure of precaution against theft or damage, or was there another motive for their concealment? Clearly, 2D and 3D images functioned on the same performative mode for the benefit of the deceased in the tomb, as substitutes for the activities, figures, objects, and products depicted (see, e.g., [29] (pp. 372-373), [46] (p. 20), [40] (p. 109), [18] (p. 100)), as a guarantee of eternal sustainment in the Beyond without any personal menial activity on the part of the official, and as a mark of his superior status (for EschenbrennerDiemer and Russo, architectural replicas suggest official workshops or prestige clients [47] (p. 167 n. 60)). Still, in the case of murals, these activities did not present the same level of integration as in architectural replicas and may have been considered a poorer substitute than their tridimensional, often cheaper counterpart. Since the deceased was the primary focalizer of the tomb's images, the visibility of the replicas was crucial for him only; the performers of the cult had no access to the replicas during the ritual performed in the chapel, but they could see its murals.

\section{Access to an Alternate Dimension}

Architectural replicas concentrate essential activities in an autonomous space: these microcosms 'have their own independent veracity: they are neither scrupulous and small reproductions of larger totalities, nor fragments of larger entities' [21] (p. 71). Mack's words are particularly pregnant here, as they underscore the separate existence of the replica's small world, an affinity with 'something less tangible' [22] (p. 7) than the structure it refers to. As we have seen, not all replicas of organized activities were inserted in an architectural 
environment, and if they were not, such lesser contextualization was closer to murals: wall scenes usually lack the minimal context of the workshop's space, ignored in favor of personnel, attitudes, tools, materials, and final products. Murals of granaries or columned pavilions in the shadow of which scribes record the cattle count [9] (pl. 13) were infrequent and more schematic than their tridimensional counterparts. On a well-defined stage, inside the built structure in which they are normally found, architectural replicas enclose an entire set of figures using professional tools and raw/worked materials. They integrate in an organized environment elements that developed separately: archaic granary replicas, Old Kingdom 'servants of the dead', tools, and foodstuff dummies. Meketre's architectural replicas, at the end of this evolution, are performatively functional, ordered, and distinct entities, whose integrity could not be matched by Middle Kingdom murals.

In Bailey's discussion of miniature Neolithic figurines, he notes that miniaturism makes 'accessible alternative worlds and alternative world-views', representing 'a tangible yet imaginary vehicle for travel through an imaginary landscape' [20] (pp. 28, 30, 34-36). Although Bailey adopts the external viewer's perspective on miniatures, his comment suits the situation of the deceased to whom the replica offered privileged access to the alternate world in which the activities took place. These autonomous, symbolic, yet functional microcosms were devoted to his needs. In the chapel, similar scenes arranged in murals were submitted for the official's eternal contemplation/inspection, as evinced by the use of maa, 'looking', applied to the tomb owner's figure [48] (pp. 30-31), [31] (pp. 70-73), [49]. In the underground contexts of the burial chamber and of the 'replicas chamber', the deceased was rarely depicted inside the replica (e.g., Meketre under the pavilion of the cattle count in Cairo JE 46724). His statue, when enclosed in the same space, was placed beside the replica [36] (p. 178) to view the activities in the same Subject separateness attested in the chapel's décor. The statue was an image of his immaterial essence, his $k a$, just like the depictions on the chapel walls (in which, traditionally locked in contemplation of the activities designed to feed him, the deceased gradually became a more dynamic figure in other types of scenes [48] (pp. 31-77)). In fact, it is usually contended that 'models were intended to provide symbolically for the owners' kas' [30] (p. 151), [36] (p. 176): indeed, the funerary cult provided for their nourishment, and the first 'serving statues' were attested in the serdab attached to the superstructure, the 'world of the $k a^{\prime}$. Furthermore, two figurines of offering bearers (assimilated to 'serving statues') found in burial chambers had an inscription addressed to the $k a$ of the deceased (Cairo JE 46772 from Saqqara Tomb 2757 of Inepuemhat, late Dynasty 11-early Dynasty 12 [50] (p. 15), and Berlin Inv. 10, now lost, from Dynasty 12 Assasif tomb of the overseer Mentuhotep [51] (folded plate); see [29] (pp. 245-246), [36] (p. 181); I thank Dr. Eschenbrenner-Diemer, whose PhD Thesis on wooden replicas is due for publication, for kindly providing data on these inscribed items). Nevertheless, among all known architectural replicas, none bears such an address to the $k a$. The $k a$ needed to be fed, but in the context of the burial chamber, without the agency of ritual performers, it was probably deemed a more complex issue. Architectural replicas may have developed to involve another manifestation of the deceased, attached to the underground chambers, in his sustainment and rebirth.

Various aspects of the deceased's individuality were addressed in the funerary context, some extremely difficult to interpret (see, e.g., [40,52,53], [54] (p. 161), [55] (87-102), [56]

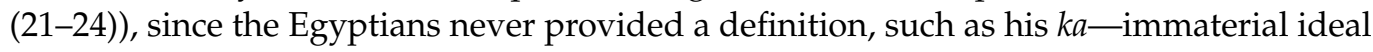
image (?) [40] (p. 151) of a social import [55] (p. 97), ba-vital [52] (p. 113) connective manifestation/power, or $a k h$-transfigured being. The chapel was devoted to the cult of

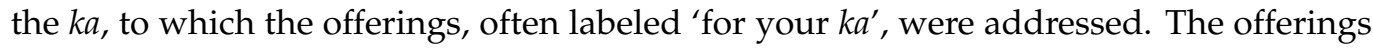
were laid in front of the false door for the $k a^{\prime}$ s benefit, a liminal feature intended for the deceased's passage from the other world. As Bolshakov puts it, 'Egyptian tomb cult is a cult of representations' [40] (p. 196), 2D and 3D images of the ka being devoted to its cult in the superstructure. The Old Kingdom sealed serdab in the tomb superstructure, its statues of the deceased and 'service' statuettes, are thus associated with the cult of the $k a$, even if these objects remain invisible to the ritualists. In contrast, the sealed subterranean chambers 
are accessed by the $b a$ to join the corpse (following the Coffin Texts, First Intermediate Period-Middle Kingdom, see infra and [52] (pp. 106-109)); Bolshakov speaks about the burial chamber as the 'world of the $b a^{\prime}$ [40] (pp. 284-285). The $b a$ is the manifestation and power of the individual that emerges from the corpse [52] (pp. 96-97), [57] (p. 3), the various 'moyens d'action du mort' [58] (p. 199), a winged mediator between the latter and the worlds of the living, of the dead, and of the gods. Flying between heaven and earth, it is a vital form of existence moved by powerful appetites [52] (pp. 94-95, 99, 101-103), a protector of the deceased to which it is attached (Coffin Texts, Spell 229: 'May my ba spend the night watching over my corpse' [59] (p. 296i)). The Dynasty 18 papyrus of Nebqed (Louvre N 3113 [60] (pl. 3)) offers an exceptional map of the tomb, suggesting for the winged $b a$ a path from the chapel to the burial chamber through the blocked shaft and the emergence of the $a k h$ from the burial chamber due to the cumulative action of (1) the ritual performed on the mummy at the entrance of the tomb; (2) the $b a^{\prime}$ s visit to the burial chamber with bread and water; and (3) the adequately furnished burial chamber with its coffin (Figure 3).

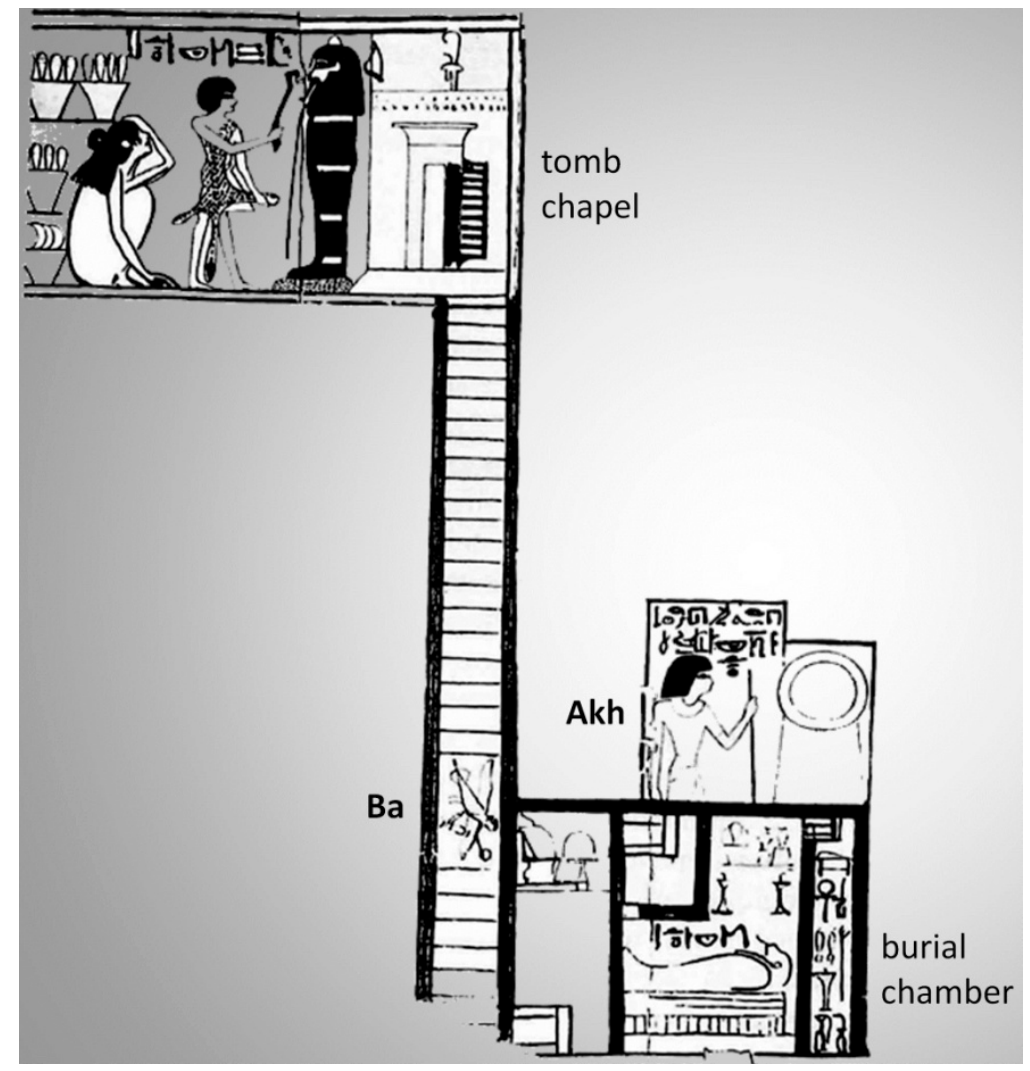

Figure 3. The tomb in papyrus Nebqed after Devéria (1872).

The private person's $b a$ is mentioned only once during the Old Kingdom, in the superstructure of the Dynasty 6 tomb of Hermeru-Merery at Saqqara [61] (p. 1-2): 'may his $k a$ be preeminent with the King, may his $b a$ endure with God.' The situation changes in the First Intermediate Period-Middle Kingdom: the $b a$ is well-attested in the Coffin Texts [52] (pp. 90-114), [40] (p. 284), a non-royal funerary corpus attached to the burial chamber. As we have seen, it is around the same period that murals appear in some burial chambers and that the ancient serdab statues of the deceased, his family, and food-production replicas have been transferred into the burial chamber. Out of the superstructure, the still concealed, mostly isolated menial figurines are grouped into generic teams dedicated to a specific service, and sometimes integrated into architectural replicas. When the burial chamber has murals, the scenes rarely involve human activities; these can be supplied by the replicas. Sealed 'replicas chambers' dug beneath the floor of the superstructure, first attested in the 
tomb of King Mentuhotep II (Dynasty 11), are features of some private Dynasty 12 tombs such as Meketre's [29] (p. 77), [5] (p. 16), [13] (pp. 127, 135). This is an intermediate option between the superstructure's cult of the $k a$ and the substructure's relation to the corpse and $b a$. In some tombs, the 'replicas chamber' and a deposit of replicas beside the coffin are both attested [62] (pp. 91-92), testifying to an evolving practice.

Most replicas were implanted into the mummy's environment, impenetrable to cult performers after the burial, but believed to be regularly accessed by the $b a$ (and other aspects of the deceased), whose attachment to the corpse was balanced by its inherent mobility, essential for survival [58] (p. 195). The idea of the deceased's mobility between various realms is omnipresent in funerary literature, accessibility being suggested by the doorway metaphor. The Coffin Texts frequently mention the doors of heaven and earth (e.g., Spell 24 [63] (p. 75)), of the Netherworld and the tomb (dwat in Spell 38 [63] (p. 161f), imht in Spell 825 [64] (p. 26a), hat in Spell 834 [64] (p. 35p)). When 'going out into the day', the deceased proclaims 'I have parted the doors of the tombs' (Spell 105 [65] (p. 113c)). Specific aspects and manifestations of the deceased are requested to open heaven's and tomb chapel's doors, e.g., Coffin Texts Spell 491 calls to the $b a$, akh, magic, and shadow of the deceased to 'open up the two leaves of heaven's door, open the tomb chapel, ascend and descend' [66] (p. 71a-d). There is a specific 'spell for opening the door to the $b a^{\prime}$ so that it may join the corpse (Coffin Texts, Spell 242 [59] (pp. 327-328)). False doors were set in the superstructure to provide the deceased with suitable access to ritual offerings; doors were also depicted on coffins, and false doors sometimes integrated in the walls of the burial chamber [40] (p. 120). As for the replicas, they were ideally placed along the east side of the coffin, close to its eye-panel, enabling a view of each sunrise, and its false door [29] (pp. 77, 82-83), implying a direct communication between the deceased and the replicas (visual communication for the mummy, access for a mobile manifestation of the deceased). Doors are a constant, important feature of architectural replicas, piercing their external walls and internal partitions; Meketre's architectural replicas all possess (pivoting) doors that provide the deceased access into their alternate dimension, to the nourishment and services he craves. I would suggest that in the sealed 'replicas chamber' and burial chamber, it is mainly the winged $b a$ that is meant to 'open' the doors of the architectural replicas, enter their imaginary realm, and feed the deceased. The replicas may have been considered parts of the deceased's funerary estate (djet) to which the $b a$ had access (Coffin Texts, Spell 314 [67] (p. 96d)). Moreover, the $b a$ brings food to the gods (e.g., Coffin Texts, Spell 102 [65] (p. 106d-e)); its freedom of motion and union with the corpse ensure the deceased's sustenance (Coffin Texts, Spell 333 [67] (p. 1781-n)).

The replicas' imaginary microcosm (tombs are also microcosms, see [68]; I thank Edmund Meltzer for sharing his views on this topic) functioned in a very similar way to the macrocosm of Djoser's pyramid complex (Dynasty 3, ca. 2650 B.C.), with its unique genuine entrance through the surrounding wall among fourteen false gates and its impenetrable dummy buildings, filled with stone, only accessed by the immaterial individuality of the dead King. Why erect petrified constructions and impenetrable doors on the desert plateau if they were not intended for royal eternal use? The King needed a space of his magnitude, a gigantic architectural replica, to transcend time and death, while deceased officials would make do with miniature replicas for eternity (actually, the earliest architectural replicas are to be found in non-royal burials). In this particular genre, Meketre's replicas are the most exquisite examples of elite material culture and, of course, an index of status in both worlds.

The opposition superstructure vs. substructure of the tomb, at the time of the Coffin Texts, may thus be schematized, on the basis of the global assessment proposed in the preceding chapters, in the following manner (Table 1): 
Table 1. Tomb superstructure vs. substructure.

\begin{tabular}{|c|c|}
\hline Superstructure & Substructure \\
\hline Open & Closed \\
\hline World of the $k a$ & World of the corpse, $b a$, and other manifestations \\
\hline Cult of the $k a$-the deceased is served by the cult & $\begin{array}{l}\text { No cult after burial-the deceased is served by his } b a \text { and } \\
\text { other manifestations }\end{array}$ \\
\hline Performative images (murals, deceased statue) & Performative images (replicas, rare murals, deceased statue) \\
\hline $\begin{array}{l}\text { The deceased contemplates 2D activities performed for his } \\
\text { benefit and accesses the offerings through the false door }\end{array}$ & $\begin{array}{c}\text { The deceased statue/mummy contemplates and the } b a \text { accesses } 3 \mathrm{D} \\
\text { replicas through their doors }\end{array}$ \\
\hline
\end{tabular}

\section{Conclusions}

Architectural replicas were made to revivify the deceased, providing him, in the inaccessible part of the burial, with the sustenance and the ability to oversee essential activities that may have been under his responsibility when he was alive. These activities were separated by walls and scale from the sealed chamber in which they were deposited, their doors offering symbolic access to eternal abundance in the Afterlife. Meketre's architectural replicas are thus, like other miniatures, 'not just out of scale, but somehow out of reality too' [22] (p. 4). During the First Intermediate Period-Middle Kingdom, architectural replicas enabled the best possible actualization of the elite funerary model inscribed in the Coffin Texts: as a connective agent between the worlds of life, death, and eternity, between humans, images, and gods, the ba played its part, along with other aspects and manifestations of the deceased, in the rebirth of his integrated self (on 'death as dissociation', see [55] (pp. 87-112)). This is clearly enounced in the Coffin Texts, Spell 304 [67] (pp. 57-58):

I'm efficient, I'm collected

My $b a$ is with me

My heart is in my body

My corpse in the earth,

I didn't weep over it.

My $b a$ is with me,

It didn't go far from me.

Magic is in my body,

It wasn't stolen.

My akh belongs to me

My manifestations belong to me

So that I may eat my meals with my $k a$ who is in this earth of mine,

So that I may rest, renewed, young again.

Funding: This research received no external funding.

Institutional Review Board Statement: Not applicable.

Informed Consent Statement: Not applicable.

Data Availability Statement: Not applicable.

Conflicts of Interest: The author declares no conflict of interest.

\section{References}

1. The British Museum. Available online: https:/ / www.britishmuseum.org/collection/object/Y_EA35505 (accessed on 22 July 2021).

2. Stadelmann, R. Hausmodelle. In Lexicon der Ägyptologie; Helck, W., Westendorf, W., Eds.; Harrassowitz: Wiesbaden, Germany, 1977; Volume 2, pp. 1067-1068.

3. Willems, H. The Coffin of Heqata (Cairo JdE 36418); Peeters (OLA 70): Leuven, Belgium, 1996.

4. Arnold, D. Amenemhat I and the Early Twelfth Dynasty at Thebes. MMJ 1991, 26, 5-48. [CrossRef]

5. Allen, J.P. Some Theban Officials of the Early Middle Kingdom. In Studies in Honor of William Kelly Simpson; der Manuelian, P., Ed.; Museum of Fine Arts: Boston, MA, USA, 1996; Volume 1, pp. 1-26. 
6. Brovarski, E. False Doors and History: The First Intermediate Period and Middle Kingdom. In Archaism and Innovation: Studies in the Culture of Middle Kingdom Egypt; Silverman, D.P., Simpson, W.K., Wegner, J., Eds.; Department of Near Eastern Languages and Civilizations, Yale University: New Haven, CT, USA; University of Pennsylvania Museum of Archaeology and Anthropology: Philadelphia, PA, USA, 2009; pp. 359-425.

7. Winlock, H.E. Models of Daily Life in Ancient Egypt from the Tomb of Meket-Re' at Thebes; The Metropolitan Museum of Art (AE 18): Cambridge, MA, USA, 1955.

8. Lepsius, C.R. Denkmäler aus Ägypten und Äthiopien: Nach den Zeichnungen der von Seiner Majestät dem Könige von Preussen Friedrich Wilhelm IV. Nach Diesen Ländern Gesendeten und in den Jahren 1842-1845; Hinrichs: Leipzig, Germany, 1849 ; Volume 2.

9. Newberry, P.E. Beni Hasan; Kegan Paul, Trench, Trübner: London, UK, 1893; Volume 1.

10. Kanawati, N.; Evans, L. The Cemetery of Meir: The Tomb of Pepyankh the Black; Aris and Phillips (ACER 34): Oxford, UK, 2014; Volume 2.

11. The Met. Available online: https:/ / www.metmuseum.org/art/collection/search\#!?q=20.3.162 (accessed on 22 July 2021).

12. Legrain, G. Notes sur la nécropole de Meir. ASAE 1900, 1, 65-72.

13. Kroenke, R. The Provincial Cemeteries of Naga ed-Deir: A Comprehensive Study of Tomb Models Dating from the Late Old Kingdom to the Late Middle Kingdom. Ph.D. Thesis, University of California, Berkeley, CA, USA, 2010. Available online: https: / / escholarship.org/uc/item/7d52746x (accessed on 22 July 2021).

14. Petrie, W.M.F. Gizeh and Rifeh; School of Archaeology in Egypt, University College, Bernard Quaritch: London, UK, 1907.

15. Kuentz, C. Bassins et tables d'offrandes. BIFAO 1981, 81, 243-282.

16. Niwinski, A. Plateaux d'offrandes et "maisons d'âmes": Genèse, évolution et fonction dans le culte des morts au temps de la XIIe dynastie. ET 1975, 8, 73-122.

17. Niwinski, A. Seelenhaus (und Opferplatte). In Lexicon der Ägyptologie; Helck, W., Westendorf, W., Eds.; Harrassowitz: Wiesbaden, Germany, 1984; Volume 5, pp. 806-813.

18. Leclère, F. Les "maisons d'âme" égyptiennes: Une tentative de mise au point. In "Maquettes Architecturales" de l'Antiquité: Regards Croisés. Actes du Colloque de Strasbourg, 3-5 Décembre 1998; Muller, B., Ed.; Diffusion De Boccard: Paris, France, 2001 ; pp. 99-121.

19. Mi, F. Architectural Models of Ancient Egypt: The Soul Houses of the Rijksmuseum van Oudheden. In Current Research in Egyptology 2019, Proceedings of the Twentieth Annual Symposium, University of Alcala, Madrid, Spain, 17-21 June 2019; Carcamo, M.A., Casado, R.S., Orozco, A.P., Robledo, S.A., Garcia, J.O., Riudavets, P.M., Eds.; Archaeopress: Oxford, UK, 2021.

20. Bailey, D.W. Prehistoric Figurines: Representation and Corporeality in the Neolithic; Routledge: London, UK; New York, NY, USA, 2005.

21. Mack, J. The Art of Small Things; Harvard University Press: Cambridge, MA, USA, 2007.

22. Davy, J.; Dixon, C. What Makes a Miniature? An Introduction. In Worlds in Minature: Contemplating Miniaturisation in Global Material Culture; Davy, J., Dixon, C., Eds.; UCL Press: London, UK, 2019; pp. 1-17.

23. Knappett, C. Meaning in Miniature: Semiotic Networks in Material Culture. In Excavating the Mind: Cross Sections through Culture, Cognition and Materiality; Johanssen, N., Jensen, M., Jensen, H.J., Eds.; Aarhus University Press: Aarhus, Denmark, 2012; pp. 87-109.

24. David, A. Renewing Royal Imagery: Akhenaten and Family in the Amarna Tombs; Brill (HES 11): Boston, MA, USA, 2021.

25. Austin, J.L. How to Do Things with Words; Oxford University Press: New York, NY, USA, 1970.

26. David, A. The Sound of the Magic Flute in Legal and Religious Registers of the Ramesside Period: Some Common Features of Two "Ritualistic Languages". In Law and Religion in Eastern Mediterranean; Kratz, R.G., Hagedorn, A.C., Eds.; Oxford University Press: Oxford, UK, 2013; pp. 13-39.

27. David, A. How to Do Things with hw: The Egyptian Performative iw-n-. In Labor Omnia Uicit Improbus: Miscellanea in Honorem Ariel Shisha-Halevy; Bosson, N., Boud'hors, A., Aufrère, S.H., Eds.; Peeters (OLA 256): Leuven, Belgium, 2017 ; pp. 411-430.

28. Lévi-Strauss, C. The Savage Mind; Weidenfeld and Nicolson: London, UK, 1966.

29. Tooley, A.M.J. Middle Kingdom Burial Customs: A Study of Wooden Models and Related Material. Ph.D. Thesis, University of Liverpool, Liverpool, UK, 1989.

30. Freed, R.E.; Doxey, D.M. The Djehutynakhts' Models. In The Secrets of Tomb 10A, Egypt 2000 BC; Freed, R.E., Ed.; MFA Publications: Boston, MA, USA, 2009; pp. 151-177.

31. Tefnin, R. Eléments pour une sémiologie de l'image égyptienne. CdE 1991, 66, 60-88. [CrossRef]

32. Willems, H. Historical and Archaeological Aspects of Egyptian Funerary Culture: Religious Ideas and Ritual Practice in Middle Kingdom Elite Cemeteries; Brill: Leiden, The Netherlands; Boston, MA, USA, 2014.

33. Badawy, A. A Monumental Gateway for a Temple of King Sety I: An Ancient Model Restored. Misc. Wilbouriana 1972, 1, 1-20.

34. Swain, S. The Use of Model Objects as Predynastic Egyptian Grave Goods: An Ancient Origin for a Dynastic Tradition. In The Archaeology of Death in the Ancient Near East; Campbell, S., Green, A., Eds.; Oxbow Books (OM 51): Oxford, UK, 1995 ; pp. 35-37.

35. Bárta, M. Serdab and Statue Placement in the Private Tombs down to the Fourth Dynasty. MDAIK 1998, 54, 65-75.

36. Eschenbrenner-Diemer, G. From the Workshop to the Grave: The Case of Wooden Funerary Models. In Company of Images: Modelling the Imaginary World of Middle Kingdom Egypt (2000-1500 BC), Proceedings of the International Conference of the EPOCHS Project Held UCL, London, UK, 18-20 September 2014; Miniaci, G., Betrò, M., Quirke, S., Eds.; Peeters (OLA 262): Leuven, Belgium, 2017; pp. 133-192.

37. Breasted, J.H. Egyptian Servant Statues; Pantheon Books (BS 13): Washington, DC, USA, 1948. 
38. Eggebrecht, A. Dienerfiguren. In Lexicon der Ägyptologie; Helck, W., Otto, E., Eds.; Harrassowitz: Wiesbaden, Germany, 1975; Volume 1, pp. 1080-1083.

39. Roth, A.M. The Meaning of Menial Labor: "Servant Statues" in Old Kingdom Serdabs. JARCE 2002, 39, 103-121. [CrossRef]

40. Bolshakov, A.O. Man and his Double in Egyptian Ideology of the Old Kingdom; Harrassowitz (ÄAT 37): Wiesbaden, Germany, 1997.

41. Dawood, K. Animate Decoration and Burial Chambers of Private Tombs during the Old Kingdom: New Evidence from the Tomb of Kairer at Saqqara. In Des Néferkarê aux Montouhotep: Travaux Archéologiques en Cours sur la Fin de la VIe Dynastie et la Première Période Intermédiaire. Actes du Colloque CNRS-Université Lumière Lyon 2, Lyon, France, 5-7 July 2001; Maison de 1'Orient et de la Méditerranée Jean Pouilloux (TMOM 40): Lyon, France, 2005; pp. 107-127.

42. Kanawati, N. Decoration of the Burial Chambers, Sarcophagi and Coffins in the Old Kingdom. In Studies in Honor of Ali Radwan; Daoud, K., Bedier, S., Abd el-Fatah, S., Eds.; Conseil Supreme des Antiquités de l'Égypte (ASAE-Suppl. 34): Cairo, Egypt, 2005; Volume 2, pp. 55-71.

43. Lashien, M. The Ultimate Destination: Decoration of Kaiemankh's Burial Chamber Reconsidered. ET 2013, $26,404-415$.

44. Bourriau, J. Patterns of Change in Burial Customs during the Middle Kingdom. In Middle Kingdom Studies; Quirke, S., Ed.; SIA Publishing: Leiden, The Netherlands, 1991; pp. 3-20.

45. Oppenheim, A. Introduction: What Was the Middle Kingdom? In Ancient Egypt Transformed: The Middle Kingdom; Oppenheim, A., Arnold, D., Arnold, D., Yamamoto, K., Eds.; The Metropolitan Musuem of Art: New York, NY, USA, 2015; pp. 1-8.

46. Tooley, A.M.J. Egyptian Models and Scenes; Shire Publications (SES 2): Princes Risborough, UK, 1995.

47. Eschenbrenner-Diemer, G.; Russo, B. Quelques particuliers inhumés à Saqqâra Nord au début du Moyen Empire. BIFAO 2014, $114,155-186$.

48. Groenewegen-Frankfort, H.A. Arrest and Movement: An. Essay on Space and Time in the Representational Art of the Ancient Near East; Faber and Faber Limited: London, UK, 1951.

49. Angenot, V. La formule mAA ("regarder") dans les tombes privées de la dix-huitième dynastie. Ph.D. Thesis, Université Libre de Bruxelles, Bruxelles, Belgium, 2003.

50. Quibell, J.E.; Hayter, A.G.K. Excavations at Saqqara-Teti Pyramid, North Side; Imprimerie de l'Institut français d'archéologie orientale: Cairo, Egypt, 1927.

51. Passalacqua, J. Catalogue Raisonné et Historique des Antiquités en Égypte; Imprimerie de C. J. Trouvé: Paris, France, 1826.

52. Žabkar, L. A Study of the Ba Concept in Ancient Egyptian Texts; The University of Chicago Press (SAOC 34): Chicago, IL, USA, 1968.

53. Englund, G. Akh: Une Notion Religieuse Dans l'Égypte Pharaonique; Almqvist \& Wiksell International (BOREAS 11): Uppsala, Sweden, 1978.

54. Allen, J.P. Ba. In The Oxford Encyclopedia of Ancient Egypt; Redford, D.B., Ed.; Oxford University Press: Oxford, UK, 2001; Volume 1, pp. 161-162.

55. Assmann, J. Death and Salvation in Ancient Egypt; Cornell University Press: Ithaca, NY, USA; London, UK, 2005.

56. Nyord, R. Seeing Perfection: Ancient Egyptian Images beyond Representation; Cambridge University Press: Cambridge, UK, 2020.

57. Janák, J. Ba. In UCLA Encyclopedia of Egyptology; Dieleman, J., Wendrich, W., Eds.; UCLA Library: Los Angeles, CA, USA, 2016; Available online: http: / / digital2.library.ucla.edu/viewItem.do?ark=21198/zz002k7g85 (accessed on 22 July 2021).

58. Donnat, S. Le Dialogue d'un homme avec son ba à la lumière de la formule 38 des Textes des Sarcophages. BIFAO 2004, 104, 191-205.

59. de Buck, A. The Egyptian Coffin Texts; The University of Chicago Press (OIP 64): Chicago, IL, USA, 1947 ; Volume 3.

60. Devéria, T. Le Papyrus de Neb-Qed (Exemplaire Hiéroglyphique du Livre des Morts); A. Franck: Paris, France, 1872.

61. Altenmüller, H. Sein Ba möge fortdauern bei Gott. SAK 1993, 20, 1-15.

62. De Meyer, M. An Isolated Middle Kingdom Tomb at Dayr al-Barsha. In The World of Middle Kingdom Egypt (2000-1550 BC): Contributions on Archaeology, Art, Religion, and Written Sources, Miniaci, G., Grajetzki, W., Eds.; Golden House Publications (MKS 2): London, UK, 2016; Volume 2, pp. 85-115.

63. de Buck, A. The Egyptian Coffin Texts; The University of Chicago Press (OIP 34): Chicago, IL, USA, $1947 ;$ Volume 1.

64. de Buck, A. The Egyptian Coffin Texts; The University of Chicago Press (OIP 87): Chicago, IL, USA, 1961 ; Volume 7.

65. de Buck, A. The Egyptian Coffin Texts; The University of Chicago Press (OIP 49): Chicago, IL, USA, 1938 ; Volume 2.

66. de Buck, A. The Egyptian Coffin Texts; The University of Chicago Press (OIP 81): Chicago, IL, USA, 1956; Volume 6.

67. de Buck, A. The Egyptian Coffin Texts; The University of Chicago Press (OIP 67): Chicago, IL, USA, 1951 ; Volume 4.

68. Kamrin, J. The Cosmos of Khnumhotep II at Beni Hasan; Kegan Paul International: London, UK; New York, NY, USA, 1999. 